\title{
Mental Hygiene and Mental Health
}

\author{
Dr. Kali Kinkar Chakraborty \\ Director, Advanced Neuropsychiatry Institute, Kolkata
}

Modern world is facing a crisis of existence including those of global warming, ecological imbalance, weather changes, ideological intolerance, pure water crisis, threat of nuclear war, psychological crisis and many more. Never have harder blows hit us than at the present time, never was competition keener, never were men so cruel to their fellow men as now. But more is yet to come in near future. We are undergoing the economic crash holocaust, persecution and disillusionment. The arrogance of a growing adult youth does not understand and respect age-old wisdom and factors like selfishness, nuclear family, loneliness, mechanical living, lack of trust, obedience and affection along with job insecurity are being added up everyday.

The ultimate result has been very serious. This has affected the mental state of human being who has to live with it. Mental as well as degenerative illness have gripped a substantial portion of the world population. One third of the population in America, the richest country with all modern gadgets at hand and the best health care, is suffering from mental illness. It is crippling the human side of man. This is the time to think and contemplate so as to find out avenues of resisting the demon right now.

What is this demon called mental illness? What do we understand by it? The D.S.M.-IV-TR defines "Mental illness as a significant, behavioural and psychological syndrome or pattern, which is associated with distress and increased risk of death, pain, disability and is not reasonable (expectedly) to respond to a particular situation (A. P. A.-2000)"

Therefore, while presenting this we have to think and apply workable methods of Mental Hygiene and Mental Health programme in order to prevent the rise of mental illness. Mental Hygiene and Mental Health together belong to the group of "Preventive
Psychiatry" rather than Immunological Psychiatry. Mental Hygiene which is a pre-requisite for the activation of Prana can help the youth to check corrosive emotions like fear, anger, anxiety and passion and to conserve inner vitality, so essential for better performance in all fields of life.

Love, affection, selflessness, tolerance, good behaviour, cultivation of good thoughts, positive thinking, lack of jealousy and ego, sympathy for others, attitude of helping a neighbour, feeling of universal brotherhood are some of the factors that can improve our Mental Hygiene, thereby leading to good Mental Health.

Mental Hygiene includes all measures taken to promote and preserve Mental Health. There are six techniques which are recommended for taking care of Mental Health, so as to keep our mind ready to tackle challenges anytime. They are as follows :

1) Transcend the environment

2) Cultivate conductive acceptance

3) Visualise the ideal self

4) Use positive affirmation

5) Practise psychological counter punching

6) Charge your internal computer chip

What is Mental Health? It is a level of psychological well-being or an absence of mental disorder. It is the psychological state of someone who is functioning at a satisfactory level of emotional and behavioural adjustment. From the perspective of positive psychological or holism, Mental Health may include an individual's ability to enjoy life and create a balance between life activities and efforts to achieve psychological resilience. According to W.H.O., Mental Health includes subjective well-being, perceived self-efficiency, autonomy, 


\section{Mental Hygiene and Mental Health}

competence of one's inter-generational dependence, self-actualisation of one's intellectual and emotional potential among others. W.H.O. further states that the well-being of an individual is encompassed in the realisation of their activities, coping with normal stress of life, productive work and contributions to their communities. However, cultural differences, subjective associates and competing professional theories - all these affect how Mental Health is defined.

The field of global Mental Health is the area of study, research and practice that places priority on improving Mental Health and achieving equality in Mental Health for all people worldwide. It is also termed behavioural well-being.

The Mental Health Bill 2013 of our country speaks about the rights and privileges of the mentally ill. Mental Health service has been recommended in all states of India. It includes the following :

1) Screening of Mental Health programme

2) Systemic allocation

3) Good behaviour

4) Assurance to person's efforts

5) Assistance to the affected people

6) Education tools to be used

7) Strengthening clinical resources

8) Broadening of mind

9) Love and hopefulness

10) Inculcating trust and self-esteem

11) Developing trust in themselves and the world

12) Growing people's relation and intimate rapport

This should include school Mental Health programme for children, adults' Mental Health education through lectures, seminars and media services, geriatric Mental Health programme for elderly teachers and their teaching skill development and specific learning objectives, promoting positive social and emotional developments for all, taking care of the psychological factors, cultural interactions, psychotherapy, counseling and education.
Now we shall try to analyse whether these managements of Mental Health and Mental Hygiene are practical and universal. The suggestions given for the management of Mental Hygiene and Mental Health seem to be so complicated and the networks are so vast that they need a very big infrastructure for interlinking them with constant vigilance, which seems impractical. Moreover, these methods involve huge amount of money which is difficult to manage even for the most developed countries of the world. Naturally, the smaller countries are bound to lag behind. Therefore, the universality of this system is questionable. Also, the problem of the individual man has not been touched here. If the individual man does not possess strong will and character the whole system is bound to end in total failure. But the attempt, no doubt, is a good one.

We shall now see how our ancient wisdom has thought about it and what is their mode of working in order to improve Mental Hygiene and Mental Health as also how much can we profit by their wisdom.

Our seers believed that man is the best creature on earth and only he has the capacity to evolve himself to the highest level of mental state. And only human beings can think about Mental Health and Mental Hygiene. Ancient thinkers believed in the individual development of man without which society cannot be elevated. If the individual is good, society at large will also be good. Unlike any other creature, man alone has the capacity to be divine (elevated mental state) and he is destined to be so.

Our wise men classified man according to their genetic aptitude into three classes : 1) The animal man 2) The human man 3) The divine man. There is, however, no watertight compartment, the classification being based on average aptitude. Therefore, one class can always get mixed into the other as because man has the immense capacity to change his Mental state. So this intermixing should be considered to be a normal phenomenon. Now let us take these up one by one. 
1) Animal Man : They have animal like characteristics and are termed Tamoguni (तमोगुणी) - an attribute attached to this class of people. They possess animal propensities like lust, greed, selfishness and run after sensual pleasures. They become thieves, dacoits, terrorists living for their own satisfaction without any kindness or tenderness for fellow members. This is probably the type of people we find in our society today. They are egoistic and ferocious, men without human qualities, quarrelling with other people, even killing them and thereby destroying the society. They live without a life of Dharma.

2) Human Man : They live with the values of humanity, believing in God and Brahma. These men always do good to the people in the society. They live with a mission of life and always try to elevate themselves to the divine. But these people are expected to believe in and follow some human values or qualities. According to Manu Samhita (मनुसंहिता), they maintain these principles in their lives, like :

a. Dhriti (घृति) - Satisfaction in any state of life you are living or have to live in this world.

b. Kshama (क्षमा) - Not to retaliate even if someone hurts you.

c. Dama (दम) - Lack of ego, no anxiety about your position, wealth, name or fame.

d. Asteya (अस्तेय) - Not to covet others' property, money or anything by cheating or forcefully grabbing them.

e. Shoucha (शैच) - Purity of your external and internal self (body and mind)

f. Indriya Nigraha (इन्द्रिय निग्रह) - Possessing the capacity to withdraw from the dictates of sense organs, to control them with a strong mind.

g. Dhee (घी) - The power to analyse things and then come to a concrete solution.

h. Satya (सत्य) - Truthfulness, never to tell a lie. Not doing anything by cheating or cunningness. i. Vidya (विद्या) - Knowledge, both mundane and spiritual.

j. Akrodha (अक्रोध) - To control your anger even if there is cause for being angry.

These ten gems or values or attributes are essential to make one a man of character and good personality and to elevate oneself, living within a changing society with these constant values as ideals.

Equipped with such ideals, can be born a new man with human values at his disposal who is equivalent to the standard one mentioned while discussing Mental Hygiene in modern science of Psychiatry. He is now a changed person and will always do good to his fellow men as well as the society and country at large. Following the path of spirituality, with the help of Yoga (Astanga or eight paths of Yoga of Patanjali : Yama (यम), Niyama (यिम), Asana (आसन), Pranayam (प्राणायाम), Pratyahar (प्रत्याहार), Dharana (धारणा), Dhyan (ध्यान), Samadhi (समाधि), he becomes a man of perfect wisdom and a picture of positive or ideal Mental Health. The Geeta has given us a role model of such a man who is ideally synonymous with a mentally healthy person as defined in the modern science of Psychiatry. This can be possible only for those who is wise and steady, having controlled his ego, developing love for all. He is said to have achieved the state of Sthitaprajna (स्थितप्रज्अ), as stated by the Geeta. This is the Human man, a Rajoguni (रजोगुणी).

We find that the very question is being raised by Arjuna during the Mahabharata war. Arjuna asks Krishna (Geeta, Chapter II, Stanza 54)

स्थितप्रज्अस्य का भाषा समाधिस्यस्य केशव ।

स्थितधी: किं प्रभाषेत किमासीत ब्रजेन किम् ।।

(Sthitaprajnastha ka bhasha samadhisthasya keshava

Sthitadhi kim prabhasheta kimasit brajet kim)

Arjuna is asking a double-forked question. 1) A description of the state of mind in the man of realisation merged in self-experience 2) Demand for an explanation of the experience which will influence his actions in outer world, when he has emerged out of the transcendental state. 
In reply the Lord said : (Geeta, Chapter II, Stanza 55) प्रजाहाति यदा कामान् सर्वान् पार्थ मनोगतान् । आत्मन्येवात्मना तुष्टः स्थितप्रज्अस्तदोच्यते ।।

\section{(Prajahati yada kaman sarban partha manogatan} Atmanyevatmana tushta sthitaprajnastadocchate)

(When a man casts off, o Partha, all the desires of the mind, he is satisfied in the self by self, then he is said to be a man of steady wisdom)

This is a brilliant summary of the mental state of a person with perfect Mental Health. As his desires have ended, he can enjoy the bliss of self.

When such a man comes to live in the society or outer world, he lives like a normal human being on earth. But he still blesses all, serves all, does good to all and thus makes this earth worth living. His mind is not shaken by adversity. Neither does he hanker after pleasure nor lament at death. He is free from all attractions and repulsions, fear, anger, danger and even loss of life. He lives like a tortoise who has withdrawn his senses from sense objects and thus attains peace and tranquility.

Our seers and all great men of this world from all fields of life - they may be great leaders, men of literature and science or politics, music, dance, art as well as many other spheres of life - believed in the growth of the individual through spiritual practices. Mental illness dare not come to such men who not only lead healthy lives but influence society as well.

But our ancient wisdom does not stop at this point also. Wise men have asked us to strive for more Arise, awake and stop not till the goal is reached - says the Upanishads. What then is this goal? It is divinity or divine life on this earth. Be God, be Brahman - this is our destiny and we all must reach there, belonging someday to class III Satwaguni (सत्वगुणी).

Therefore the transition of man is from Animal man to Human man and then to Divine man. This is a long spiritual journey which turns man into God and ultimately Brahman, termed together here as Divine man. This is not a bumpy ride but a smooth sailing in the ocean of spirituality by practising yoga through the gradual process of being and becoming.
This is one great assurance that our Shastras give us.

To this enlightened class belong great ones like Buddha, Shankar, Mohammad, Jesus, Chaitanya, Ramakrishna, Vivekananda, even Satgurus and saints including our Rishis and Munis and thousands of people throughout the world in different era. They came to this earth to teach the people the right path suitable at that time of social condition and show them the way to emancipation from worldly matters, leading to peace and Ananda or bliss.

We have tried to describe both the systems, modern and ancient, for the prevention of mental illness.

Now is the question as to how these two can be synthesised and where their meeting point is. The answer lies in a new movement to be initiated in order to reduce the burden of mental illness. This new approach should include accepting and adapting the concept of individuality of man, taking up the mission of spreading the education highlighting the Human man (Rajoguni). This slogan should spread throughout the world by mass or media movement with man to man communication by practising the ten gems of human values along with application of modern preventive methods suggested by the science of Psychiatry. This is a global problem and needs to be tackled globally involving government and private enterprises including N.G.O.s - a process which should start at the primary level of education. Two parallel systems working together will do the miracle of reducing the onslaught of mental illness.

\section{REFERENCES}
1) Britannica.com
2) Businessinsiders.com
3) Manusamhita
4) Yoga of Patanjali
5) Upanishads
6) Works of Swami Vivekananda
7) Works of Swami Abhedananda
8) Geeta, Chapter II
9) D.S.M.-IV-TR
10) W.H.O. Declarations 